\title{
How the factor of reading hours affect extensive reading of teenage elementary level students at North America International School
}

\author{
Dang Hoang Bich Tram ${ }^{1 *}$, Huynh Cong Minh Hung ${ }^{1}$ \\ ${ }^{1}$ Ho Chi Minh City Open University, Vietnam \\ *Corresponding author: tramdhb.168t@ou.edu.vn
}

\begin{abstract}
ARTICLE INFO
ABSTRACT

DOI: $10.46223 / \mathrm{HCMCOUJS.}$ soci.en.8.2.283.2018

Extensive reading has been received much attention because of its benefits for second language learners. This paper aims to determine the effect of the reading hour factor on the efficiency Received: October $30^{\text {th }}, 2018$ Revised: November $19^{\text {th }}, 2018$ Accepted: December $6^{\text {th }}, 2018$ of extensive reading process of teenage students at North America International School. The experiment was conducted so as to find out whether increasing reading hours have any impact on learners reading performance. The study implications could either announce the teachers and educators the relationship between reading hours and extensive reading or employ in Keywords:

comprehensible input, extensive reading, graded reader teaching and learning reading extensively. Besides, the revealed findings will provide the teachers proper insights into implementing a successful extensive reading program.
\end{abstract}

\section{Introduction}

\subsection{Research problem}

Extensive Reading (ER) is defined as "sustained silent reading" (Day \& Bamford, 1998), "reading for pleasure" (Anaso \& Nwabudike, 2013) or an implicit way of learning the language (Lee \& Mallinder, 2017). Benettayeb (2010) also explains that ER can keep contact with English at home and by gradually absorbing the language in their favorite materials that readers may forget that they are reading but pursuing the only aim is understanding the text. By the same token, Harmer (2015) also agrees with Benettayeb (2010) in terms of the place where ER usually takes place - outside the classroom and read at their own pace. He adds that students are likely to enjoy reading and gradually, they not only acquire the language but also establish a sense for L2. In the light of Extensive Reading principles, the students might choose what they want to read and read as much as possible for comprehension. Besides, ER is defined as a promising instructional method for enhancing students' language learning regarding to vocabulary leaning, reading fluency, spelling and motivation in the second language (L2) learning (Benettayeb, 2010) because learners have high chances to read a large number of books in a long time.

According to Davies and Pearse (2000), vocabulary plays a crucial role in learning the target language because without the necessary vocabulary, learners cannot use the language effectively. As Nation (2001) mentioned, vocabulary development means learners' vocabulary 
size is increasing. It is believed that the students need to remember as more words as possible so as to prove that their vocabulary is rising. Fortunately, ER could fulfill the needs of increasing learners' vocabulary because they have more opportunities to read as much as possible the materials outside the classroom. Being given a large amount of reading texts written input, learners could gradually obtain the words by repeatedly encountering them.

Krashen (1993) reveals that ER could supply the learners with comprehensible input which is the understandable language through reading large amounts of reading texts. Specifically, these reading materials are normally at or lower than the students' current language level and presented vividly with interesting and attractive topics. Comprehensible Input Hypothesis claims that students should be exposed to the understandable input, in this case, the reading text so that learners could approach it easier and faster. In this way, their language attitude could be maintained and motivation in reading is raised.

The theoretical framework of ER is basing on not only comprehensible input but also incidental learning. Nation (2011) holds that vocabulary can only be acquired by incidentally exposing many times and learning vocabulary should not be separated from other skills but an integrated process will result in better learning. Learning vocabulary through reading is concerned as an incremental process. According to Nation (2011), reading extensively helps the students to acquire the vocabulary constantly and incidentally. He hypothesizes that lexical items should be incidentally acquired from more than one single exposure. In this way, the vocabulary can be developed and remembered better in long term memory and meaningful exposure to a word from ER could contribute to the acquisition of the word more frequently than the intensive reading. Additionally, Schmitt (2006) reached a consensus that providing that the learners read English materials extensively, L2 spelling, grammar and phonological learning could be beneficial because of the repetition of the words presented continuously through the materials (Day \& Bamford, 1998). Nation (2009) agreed with this view by pointing out that graded readers - a representative of extensive reading strongly affects students' vocabulary acquisition because of the simplified language which the readers gain in reading texts.

As cited in Waring and Takaki (2003), in incidental learning through ER, one half of the learned vocabulary would likely to be lost after three months which means more and more chances to expose to the words is totally necessary for memorizing them. Nation and Meister (1978, as cited in Teng, 2015) also indicate that the students need to encounter new words after the first meeting at least eight instances so that they could remember the words after three months. In this experiment, the researcher will investigate the benefit of reading hours of the two groups on the increasing vocabulary in the ER experiment.

As stated in Waring (2011), readers have to read at least 1 hour a day so as to achieve the benefit of ER on vocabulary development. More important, readers have to read within a long time from three months or above with the appropriate reading materials. The more they read, the more chances they have to encounter the words. It is described that in the condition of obtaining a word, students have to meet it at least 8 times. As a result, the more hours students spend on reading, the more chances they might have to meet the words.

Though ER has been introduced since 1998 by Day and Bamford, not many studies on ER were carried out in Viet Nam. By the same token, some researchers and educators still doubt the effectiveness of ER and do not know exactly what factors are crucial in achieving ER success. Therefore, this study aims at providing the effect of reading hour factor on ER 
experiment. Based on the previous literature review, the experiment had the following aims. Firstly, the experiment objective is to find out whether the reading hours could affect the ER experiment because this factor is not emphasized in any ER study but the factors that strongly affect ER normally are reading materials, readers and the course features. The experiment assumed that increasing reading hours within three months could affect the efficiency of ER. Secondly, the experiment would report the hour's students read in the ER with the assumption that how the reading hours change and how the ER performance is affected.

\section{Research question}

To what extent, does reading hours affect the benefits of extensive reading on elementary students at North America International school?

\section{Method}

\section{Participants}

The study was conducted at North America International School in Tan Phu district. Sixty students from two classes in TEEN 7 class are chosen to participate in this study. They are divided into 2 groups, half of them are in the experimental group (EG) and 30 students are in the control group (CG) and they all are at Elementary level. The experiment lasted s12 weeks. There were 3 one and a half class meetings each week. The participants learned English for more than 5 years and they have attended English courses at North America International School for more than 1 year. Their age is ranging from 12 to 15 years old. Among thirty students of two groups, 15 students are male and 15 are female.

\section{Materials}

In this experiment, students learned Unit 1 and Unit 2 of the coursebook Got it level 2 by Philippa Bowen and Denis Delaney (2011), published by Oxford University Press: student book and workbook. Before jumping to the first unit, students had to spend one week to go through the first part of the coursebook that is "welcome" - a review of the prerequisite language knowledge of some vocabulary according to the basic topics and certain grammars that the students had to know. Then moving up next to Unit 1 of the book - "Nobody lives here" the vocabulary content was about places and town, grammar contents were learning about must forms, compounds such as some, any, no, every. Besides, the unit communication objectives were introducing students how to ask and give directions and practicing pronouncing $/ \mathrm{r} /$ sound while guaranteeing to provide the students with high chances to improve their language skills through reading a magazine article about online safety, listening to a police officer talking about road safety, speaking about road safety rules and writing a text of safety rules. In Unit 2 - "I have to clean my room" would be introduced. In this unit, the vocabulary contents were about housework, and the grammar points were "have to, must not/ don't have to and gerund/to infinitive". Also, communication contents provided learners the fixed expressions of asking for permission and pronunciation practice between "have/ hæv/" and "have to /hæf "tə/". Not only communication was focused, four language skills also addressed by reading a magazine article about active teenagers, listening to a radio show about lazy teenagers, speaking about asking and answering homework questions and writing a weekly schedule text.

Together with the textbook, Macmillan graded readers were considered as a treatment of this experiment. Owing to the students' current level - elementary level which means the 
participants of the two groups would read extensively the Graded Readers mostly from Starter to Elementary level only some were Pre-intermediate level.

Table 1

The number of words at each level of Macmillan Readers

\begin{tabular}{|l|c|l|}
\hline \multicolumn{2}{|l|}{ Level } & Number of words \\
\hline Starter - A1 & A1 & About 300 basic words \\
\hline Beginner - A2 & A1 & About 600 basic words \\
\hline Elementary & A2 & About 1100 basic words \\
\hline Pre - Intermediate & A2 - B1 & About 1400 basic words \\
\hline Intermediate & B1 & About 1600 basic words \\
\hline Upper & B2 & About 2200 basic words. \\
\hline
\end{tabular}

Source: The researcher's data analysis

\section{Procedure}

At the beginning of the study, a vocabulary test was delivered to 2 groups so as to determine learners' vocabulary size. The Vocabulary Levels Test suggested by (Nation, 2008) was extracted from https://www.lextutor.ca/tests/levels/recognitio n/1_14k/to. The data of pre and post-test are compared after three months providing treatment. Besides, after finishing two graded readers, the students were asked to fill in the reading diary (Appendix 1) to report the hours they had spent on reading each week and the new words. The data from their reading report and pre and post-test on vocabulary were analyzed so as to prove the hypothesis.

\section{Scoring}

The current study used SPSS 23 for windows for the statistical analysis measures (i) the descriptive statistic of reading hours of two groups, (ii) the t-test to compare the mean scores between EG and CG in order to examine the similarity of the pre-test and the difference of posttest, (iii) and the correlation between the reading hours of CG to its vocabulary tests with the reading hour of EG to its vocabulary tests.

\section{Table 2}

Comparing to the reading hours of $\mathrm{CG}$ and EG

Descriptive Statistics

\begin{tabular}{|l|r|r|r|r|r|}
\hline & N & Minimum & Maximum & Mean & Std. Deviation \\
\hline CG & 30 & 60.50 & 85.80 & 74.2317 & 5.59648 \\
EG & 30 & 73.75 & 88.45 & 81.3917 & 4.21794 \\
Valid N (listwise) & 30 & & & & \\
\hline
\end{tabular}

Source: The researcher's data analysis

As revealed in Table 1, within 3 months, the minimum reading hours of $\mathrm{CG}$ is 60.50 hours while it is lower in EG with 73.75. Besides, the maximum reading hours of CG is also proved to be lower with 85.80 hours whereas EG achieves 88.45 hours. The results from the 
means of two groups indicate that EG spent more time in reading than CG because its mean is 81.39 and this number is greater than in CG $10 \%$ (74.23). The data analyzed could show that EG spends more time on reading because they are guided to read as much as they can and they could have a bonus for the ones who read which the highest hours in the week.

\section{Table 3}

Results of T-test for pre and post-test of the first 1000 - word vocabulary

\section{Paired Samples Test}

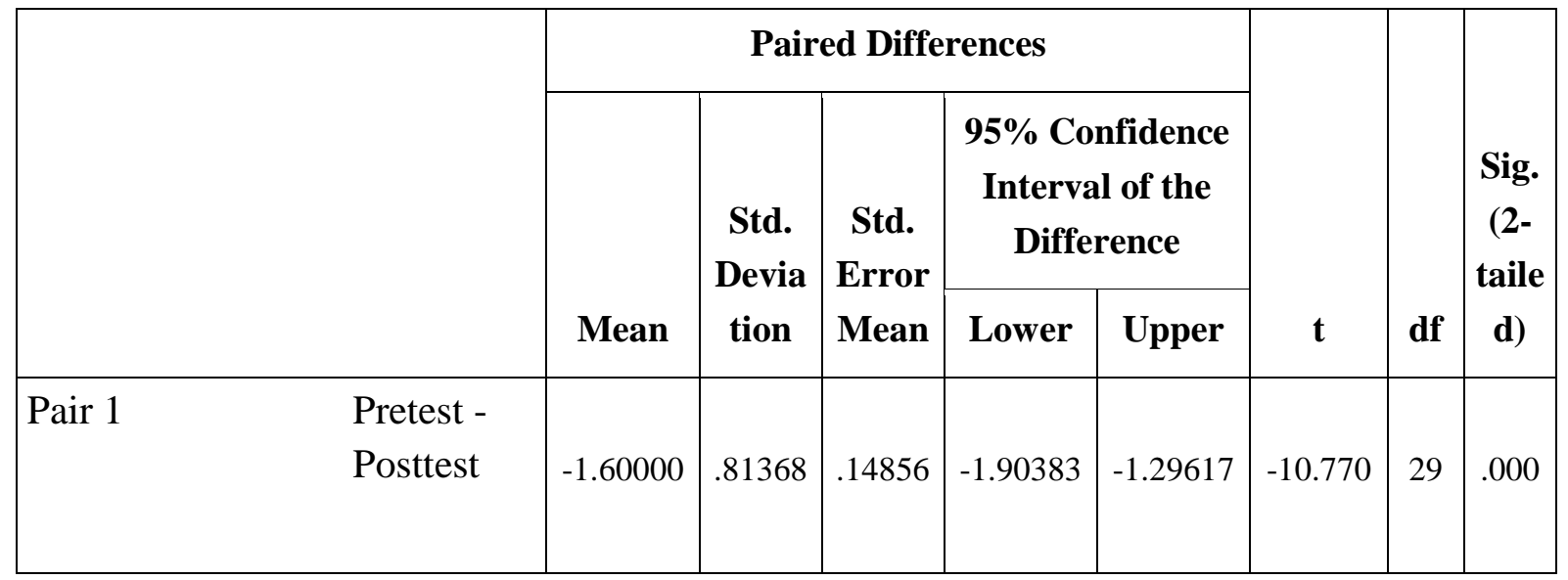

Paired Samples Statistics

\begin{tabular}{|ll|c|c|c|c|}
\hline & & Mean & N & Std. Deviation & Std. Error Mean \\
\hline Pair 1 & Pretest & 6.2000 & 30 & .88668 & .16189 \\
\cline { 3 - 6 } & Posttest & 7.8000 & 30 & .76112 & .13896 \\
\hline
\end{tabular}

Source: Data analysis result of the research

As shown in Table 3, there is a statistically significant difference $(\alpha \leq 0.005)$ between the pre - and post-tests of EG attributed to the difference in the treatment (ER) of the post-test. It should be noted that the $T$ value was $(-10.770)$. This reaches the significance at $(\alpha \leq 0.005)$. According to the data, the null hypothesis that is there are not any statistically significant differences at $(\alpha \leq 0.005)$ in the mean scores of the participants' first 1000 vocabulary size between the two tests (pre - and post-test) that was rejected. While the mean score of the vocabulary size in the post-test (7.8000) higher than the pre-test (6.2000). The analyzed data revealed that there is a significance in the first 1000 words. The result could reveal that there is an improvement in 1000 vocabulary words of EG in 14000 vocabulary level test if the participants were required to read extensively outside the classroom with their favorite materials. 


\section{Table 4}

Results of T-test for pre and post-test of the second 1000 - word vocabulary

\section{Paired Samples Statistics}

\begin{tabular}{|ll|c|c|c|c|}
\hline & & Mean & N & Std. Deviation & Std. Error Mean \\
\hline Pair 1 & Pretest2k & 5.1333 & 30 & 1.13664 & .20752 \\
\cline { 2 - 5 } & Posttest2k & 6.7333 & 30 & 1.04826 & .19139 \\
\hline
\end{tabular}

Paired Samples Test

\begin{tabular}{|c|c|c|c|c|c|c|c|c|c|}
\hline & & \multicolumn{5}{|c|}{ Paired Differences } & \multirow{3}{*}{$\mathbf{t}$} & \multirow{3}{*}{ df } & \multirow{3}{*}{$\begin{array}{l}\text { Sig. } \\
\text { (2- } \\
\text { taile } \\
\text { d) }\end{array}$} \\
\hline & & \multirow[t]{2}{*}{ Mean } & \multirow[t]{2}{*}{$\begin{array}{c}\text { Std. } \\
\text { Deviation }\end{array}$} & \multirow{2}{*}{$\begin{array}{l}\text { Std. } \\
\text { Error } \\
\text { Mean }\end{array}$} & \multicolumn{2}{|c|}{$\begin{array}{l}\text { 95\% Confidence } \\
\text { Interval of the } \\
\text { Difference }\end{array}$} & & & \\
\hline & & & & & Lower & Upper & & & \\
\hline Pair 1 & $\begin{array}{l}\text { Pretest } 2 \mathrm{k} \text { - } \\
\text { Posttest } 2 \mathrm{k}\end{array}$ & -1.60000 & .85501 & .15610 & -1.91926 & -1.28074 & -10.250 & 29 & .000 \\
\hline
\end{tabular}

Source: Data analysis result of the research

As presented in Table 4, the second 1000 words of pre-test and post-test of EG statistically significant at $.000(\alpha \leq 0.005)$ which clearly points out that there is a crucial difference between the pre and post-test of the second 1000 words of EG. Moreover, the $t$ value is (-10.025). According to Table 4, hypothesis that is there are statistically significant differences at $(\alpha \leq 0.005)$ in the mean scores of the participants' second 1000 - word vocabulary size between the two test (pre - and post-test) that was proved. While the mean score of the vocabulary size in the post-test (6.7333) is higher than the pre-test (5.1333). This result indicates that students have increased their vocabulary in the next 1000 words of the 14 thousand vocabulary level test. This result once again proves that asking the students to read extensively in three months would improve the students' vocabulary size.

\section{Table 5}

Results of T-test for pre and post-test of the third 1000 - word vocabulary

Paired Samples Statistics

\begin{tabular}{|ll|c|c|c|c|}
\hline & & Mean & N & Std. Deviation & Std. Error Mean \\
\hline Pair 1 & Pretest3k & 5.5000 & 30 & .82001 & .14971 \\
& Posttest3k & 6.8000 & 30 & .84690 & .15462 \\
\hline
\end{tabular}


Paired Samples Test

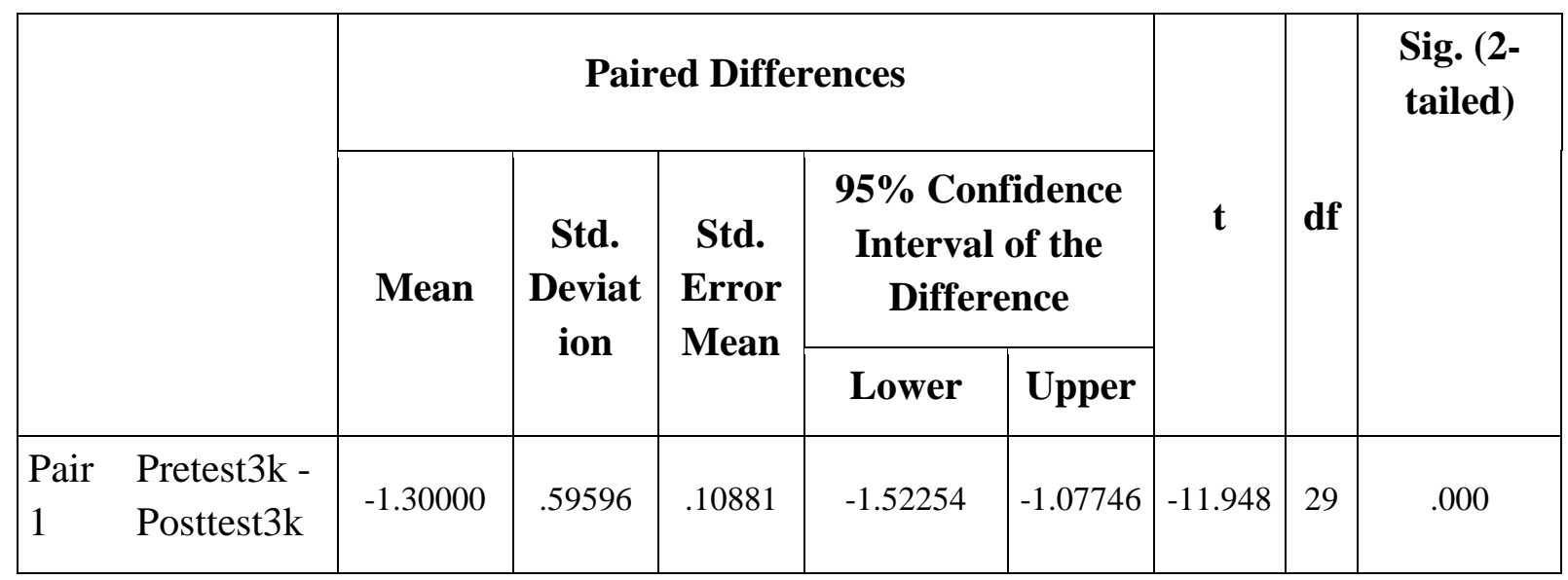

Source: Data analysis result of the research

Table 5 shows the vocabulary post-test scores of pre and post-test participants of EG. The mean of the post-test scores of EG was 6.8000, while that of CG was 5.5000. The T - value for the vocabulary post-test scores of EG was -11.948 . The significant difference between the vocabulary pre and post-test scores was at the significance level at $.000(\alpha \leq 0.005)$. This means that there was found a significant difference between pre and post-test of the third 1000 - word level of 14 thousand word level tests. Therefore, these results confirm that there is a greater improvement in the vocabulary of EG after receiving the treatment.

\section{Table 6}

Pre and post-test of CG on 14k Vocabulary test

\section{Paired Samples Statistics}

\begin{tabular}{|l|l|c|c|c|c|}
\hline \multicolumn{2}{|l}{} & Mean & N & Std. Deviation & Std. Error Mean \\
\hline Pair 1 & PreCG1k & 63.0000 & 30 & 9.87857 & 1.80357 \\
\cline { 4 - 6 } & PostCG1k & 69.0000 & 30 & 9.22889 & 1.68496 \\
\cline { 4 - 6 } & PreCG2k & 53.6667 & 30 & 11.29032 & 2.06132 \\
\cline { 3 - 6 } & PostCG2k & 63.6667 & 30 & 11.88547 & 2.16998 \\
\cline { 4 - 6 } Pair 3 & PreCG3k & 49.6667 & 30 & 11.29032 & 2.06132 \\
\cline { 3 - 6 } & PostCG3k & 59.3333 & 30 & 12.57620 & 2.29609 \\
\hline
\end{tabular}




\begin{tabular}{|c|c|c|c|c|c|c|c|c|c|}
\hline \multicolumn{10}{|c|}{ Paired Samples Test } \\
\hline & & \multicolumn{5}{|c|}{ Paired Differences } & \multirow{3}{*}{$\mathbf{t}$} & \multirow{3}{*}{ df } & \multirow{3}{*}{$\begin{array}{l}\text { Sig. } \\
(2- \\
\text { tailed })\end{array}$} \\
\hline & & \multirow[t]{2}{*}{ Mean } & \multirow{2}{*}{$\begin{array}{c}\text { Std. } \\
\text { Deviation }\end{array}$} & \multirow{2}{*}{$\begin{array}{l}\text { Std. } \\
\text { Error } \\
\text { Mean }\end{array}$} & \multicolumn{2}{|c|}{$\begin{array}{c}95 \% \text { Confidence } \\
\text { Interval of the } \\
\text { Difference }\end{array}$} & & & \\
\hline & & & & & Lower & Upper & & & \\
\hline $\begin{array}{l}\text { Pair } \\
1\end{array}$ & $\begin{array}{l}\text { PreCG1k - } \\
\text { PostCG1k }\end{array}$ & -6.00000 & 10.03442 & 1.83203 & -9.74692 & -2.25308 & -3.275 & 29 & .003 \\
\hline $\begin{array}{l}\text { Pair } \\
2\end{array}$ & $\begin{array}{l}\text { PreCG2k - } \\
\text { PostCG2k }\end{array}$ & -10.00000 & 9.09718 & 1.66091 & -13.39694 & -6.60306 & -6.021 & 29 & .000 \\
\hline $\begin{array}{l}\text { Pair } \\
3\end{array}$ & $\begin{array}{l}\text { PreCG3k - } \\
\text { PostCG3k }\end{array}$ & -9.66667 & 10.66200 & 1.94661 & -13.64792 & -5.68541 & -4.966 & 29 & .000 \\
\hline
\end{tabular}

Source: Data analysis result of the research

Table 6 shows the result of pre and post-test of the first, second and third 1000 level of 14000 vocabulary level test, post- test scores of EG and CG. The mean of the post-tests in the second and third 1000 words test scores of CG were greater $(69.000,63.6667)$ than in the pretests $(63.0000,53.6667)$. The analyzed data shows the significant difference between the vocabulary pre and post-tests scores of the CG was at the significance level of 0.000 and 0.000 $(<0.005)$. However, the statistically less difference was found between the pre and post-test of the first 1000 - word level as the significance level of $0.003(<0.0005)$. The data analyzed indicates that there is an improvement in the second and third 1000 - word level Test after employing Extensive reading; however, the first 1000- word test scores were found to be less increased after reading extensively. This result could be explained by the reading hour factor in ER process. Practically, the participants of CG spent less time reading extensively than the EG which could be the cause of not increasing scores in the first 1000 - word tests.

Table 7

Post-tests of CG and EG in vocabulary test at NIS

One-Sample Statistics

\begin{tabular}{|l|c|c|c|c|}
\hline & N & Mean & Std. Deviation & Std. Error Mean \\
\hline PCC & 30 & 6.6833 & .98684 & .18017 \\
PEG & 30 & 6.8167 & 1.11017 & .20269 \\
\hline
\end{tabular}

Source: The researcher's data analysis

As shown in Table 7, the vocabulary post - tests score of the school NIS two groups CC and EG. The mean of EG (6.8167) was greater than in CG (6.6833). This means that there was found a significant difference between the EG and CG at the mean of the participants of two groups. In the other words, this result means that the EG's mean was significantly higher than 
the CG's mean scores. Therefore, these results confirm that there is a greater improvement in vocabulary of EG and of CG.

\section{Discussion}

As expected, the results show that after employing the treatment, there was a significant interaction between the reading hour and the vocabulary test result of two groups - CG and EG. By examining the vocabulary size through two types of tests which are the Nation's Vocabulary Level Test and the school final test, some conclusions could be drawn. Regarding the EG, the test results of pre and post-tests was found to be higher which means the participants of EG did increase their vocabulary size after reading graded readers extensively. In addition, concerning the $\mathrm{CG}$, the results also revealed that ER is apparently beneficial to the participants and this was proved by the increasing score of the pre and post-test on Vocabulary of CG in both tests, one is the school final test and one is in 14000 - word level test. The results demonstrated that, for the expert group, the vocabulary test result was outperformed the control group and there was a significant improvement in the vocabulary size of the students of EG. Besides, the reading hour factor was also investigated which clearly points out that EG spent more time on ER (10\%) than that of CG which makes the test results of EG outperformed that of CG. Guaranteeing the other factors of ER, the study did find out not only the students' level and reading materials affect the reading process but the reading hour students spend also play a significant role in generating the benefits of ER.

\section{Implications}

Concerning the educational implications, the results of this paper suggest that more and more ER programs need to be implemented with a longer reading time and reading hours in order to push the benefits of ER on vocabulary into a higher limit. More than three months or even a semester (6 months) for reading extensively are more achievable than less than 3 months.

Furthermore, the current study provides the educators and researchers some new insights into the factors of employing ER that is while employing ER, students would achieve a higher result in L2 learning if they spend more time on reading. However, to boost language result to a higher level, teachers should guide the students to choose the materials which are appropriate to both their current level, interest and lastly, the topic of the lesson in class.

Additionally, the main results of the paper revealed that the teachers should guarantee such factors as the reading hour, reading materials, and readers' level so as to have a successful ER program. One more point is that teachers should explain the advantage outcomes of ER and read extensively so that the students could imitate their teacher.

\section{Conclusion}

The present study found that there is a call in ER for EFL learners and to make sure the ER experiment succeed, teachers should try to increase the reading time students spend on ER so as to expand the advantages of ER on many language skills and aspects, especially vocabulary size. The significant relationship between reading hour factor and the success of ER is indicated to be a correlation. As a result, the teachers should consider reading hour factor when employing reading extensively. 


\section{References}

Anaso, G., \& Nwabudike, C. E. (2013). The effects of extensive reading on ESL learners' vocabulary development: A case study of Nigerian - Turkish international colleges, Kano. International Journal of Humanities and Social Science Invention, 2(4), 34-42.

Benettayeb, A. (2010). Extensive reading and vocabulary teaching. Revue Academique des Etudes Cociales et Humaines, 3(1), 20-30.

Bowen, P., \& Delaney, D. (2011). Got It! Plus, Level 2. Oxford, UK: Oxford University Press.

Brown, H. D. (2007). Principles of language learning and teaching. New York, NY: Pearson Education.

Davies, P., \& Pearse, E. (2000). Success in English teaching. Oxford, UK: Oxford University Press.

Day, R. R., \& Bamford, J. (1998). Extensive reading in second language classroom. Cambridge, UK: Cambridge University Press.

Gass, S. M., \& Selinker, L. (2008). Second language acquisition: An introductory course. New York, NY: Taylor and Francis e-Library.

Ghanbari, M., \& Marzban, A. (2014). Effect of extensive reading on incidental vocabulary retention. Procedia - Social and Behavioral Science, 116, 3854 - 3858.

Grabe, W., \& Fredricka, L. S. (2014). Teaching reading for academic purposes. In M. CelceMurcia \& D. M. Briton, Teaching English as a second or foreign language (pp. 189-205). Boston, MA: Sherrise Roehr.

Harmer, J. (2015). The practice of English language teaching. Slovakia: Pearson Education Limited.

Herrmann, A. (2013). Effects of extensive reading on writing in term of vocabulary. Indiana Teachers of English to Speakers of Other Languages Journal, 10, 53-63.

Hsu, Y. Y., \& Lee, S. Y. (2007). Extensive reading and EFL junior college students in Taiwan. Retrieved March 20, 2018, from https://web.ntpu.edu.tw/ lwen/publications/Hsu_Lee_SELL2007.pdf

Iqbal, S. A. (2017). The impact of extensive reading on learning and increasing vocabulary at elementary level. Studies in English language Teaching, 5(3), 481-494.

Krashen, S. (1993). The case for free voluntary reading. The Canadian Modern Language Review, 50, 72-82.

Lee, H. N., \& Mallinder, M. (2017). Role of extensive reading in EFL vocabulary development: Review and recommendation. The English Teacher, 40, 145-163.

LightBrown, P. M., \& Spada, N. (2008). How languages are learned. Hong Kong: Oxford University Press.

Nation, I. S. P. (2001). Learning vocabulary in another language. Cambridge, UK: Cambridge University Press.

Nation, I. S. P. (2009). Teaching ESL/EFL reading and writing. New York, NY: Routledge.

Nation, I. S. P. (2008). Teaching vocabulary. Boston, MA: Heinle.

Nation, I. S. P. (2011). Research into practice: Vocabulary. Language Teaching, 44(4), 529539. 
Renadya, W. A., \& Jacobs, G. M. (2016). Extensive reading and listening in the L2 classroom. In W. A. Renadya \& G. M. Jacobs (Eds.), English language teaching today (pp. 97-109). Cham, Switzerland: Springer International Publishing Switzerland.

Teng, F. (2015). The Effectiveness of Extensive Reading on EFL learners' vocabulary learning: Incidental versus intentional learning. Brazilian English Language Teaching Journal, 6, 66-80.

Waring, R. (2011). Extensive reading in English teaching. In H. P. Widodo \& A. Cirocki, Innovation and creativity in ELT methodology (pp. 1-14). New York, NY: Nova Publisher.

Waring, R., \& Takaki, M. (2003). At what rate do learners learn and retain new vocabulary from reading a graded reader? Reading in a Foreign Language, 15, 130-163. 